CATALAN REVIEW

Catalan Review

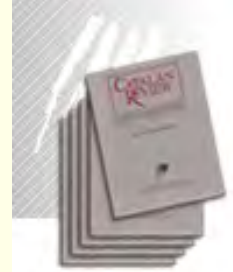

You are accessing the Digital Archive of the Catalan Review Journal.

By accessing and/or using this Digital Archive, you accept and agree to abide by the Terms and Conditions of Use available at http://www.nacs-

catalanstudies.org/catalan review.html

Catalan Review is the premier international scholarly journal devoted to all aspects of Catalan culture. By Catalan culture is understood all manifestations of intellectual and artistic life produced in the Catalan language or in the geographical areas where Catalan is spoken. Catalan Review has been in publication since 1986.
NORTH

AMERICAN

CATALAN

SOCIETY
Esteu accedint a l'Arxiu Digital del Catalan Review

A l' accedir i / o utilitzar aquest Arxiu Digital, vostè accepta i es compromet a complir els termes i condicions d'ús disponibles a http://www.nacs-

catalanstudies.org/catalan review.html

Catalan Review és la primera revista internacional dedicada a tots els aspectes de la cultura catalana. Per la cultura catalana s'entén totes les manifestacions de la vida intel lectual i artística produïda en llengua catalana o en les zones geogràfiques on es parla català. Catalan Review es publica des de 1986.

\title{
Agents of an Intersystem: Contributions of the Cuba-Based Diaspora to the Construction of the Nation in Galicia and Catalonia Thomas S. Harrington
}

Catalan Review, Vol. XV, No. 2 (2001), p. 95-114 


\title{
AGENTS OF AN INTERSYSTEM: CONTRIBUTIONS OF THE CUBA-BASED DIASPORA TO THE CONSTRUCTION OF THE NATION IN GALICIA AND CATALONIA
}

\author{
THOMAS S. HARRINGTON
}

La ciutat cremada (1976), Antoni Ribas's landmark film about the genesis of the early nationalist movement in Catalonia, ${ }^{\mathrm{I}}$ opens with a sequence showing haggard Cuban War veterans returning home to Barcelona by steamship in early 1899 . In a stateroom above the main deck, Frederic Palau, a Catalan merchant who had been living on the Caribbean island, lies in bed struggling for his life. Beside him stands an enlisted soldier carrying a backpack filled with the cash that the businessman accumulated in his years away from home. Palau, like the Catalan bourgeoisie he is clearly intended to represent, eventually recovers from the ailments inflicted on him (metaphorically at least) by the central government's mismanagement of its colonial enterprise, and when he does, he and his brother use the proceeds from their former business in Cuba to support the budding nationalist movement in their homeland. Sixty-five years before Ribas's film, Eugeni d'Ors had informed the readers of his Glossari that Teresa, la Ben Plantada, "el ideal feminino del noucentisme" (Dupláa 79), had been born in Asunción to a family from el Garraf (the traditional heartland of Catalan emigration to America) and that this contact with American culture had made them, and hence the Catalan nation which they were meant to represent, more existentially vital. And earlier still, in L'Atlàntida (1877), an epic poem finished during his time as chaplain aboard a steamer running between Barcelona and Havana, Verdaguer had presented the great ocean and the vast lands on its western edge as fundamental sources of Catalan cultural rejuvenation (Reguant 49-70). The symbolic repertoire of twentieth century Galician identity contains similar insinuations of an important "cultural commerce" 2 between the emigrant communities

I For an in-depth analysis of the political strategies inscribed in this foundational work of contemporary Catalan cinema, see Harrington, "In-House."

2 "Cultural commerce" is a term that I have developed to describe the strategic importation of cultural models from one cultural system to another. It is an attempt to expand the more limited notion (in the sense of being almost wholly concerned with textural production) of "literary interference" first posited by Itamar Even-Zohar in his series of studies on Polysystems Theory. See Even-Zohar, "Laws" 53-72. 
in America and those devoted to the nationalization of public space at home. There, however, the contributions of the overseas communities are not to be found so much such in the realm of literary and cinematic expression but rather in the creation of buildings, monuments and cultural institutions, a prime example of which is the emigrant-funded statute of Rosalía de Castro which presides over the graceful alameda of the town of Padrón just outside of Santiago. ${ }^{3}$ This creative symbiosis between diasporic communities in America and the development of late nineteenth and early twentieth century European nationalism suggested by the above examples is not, of course, unique to Galicia and Catalonia. The Czech, Slovak, Lithuanian, and Polish communities of North America were instrumental to the process of (re)defining autonomous concepts of identity for their respective homelands in the decades both before, and just after, the break-up of the Habsburg Empire in 1918. And as Nuñez Seixas reminds us, the concept of "a sea-divided Gael" (O galeguismo 45) was an integral part of Irish nationalist ideology in the years leading to the Easter Rising of 1916.

And yet, despite the apparent frequency and importance of such cultural flows, a rigorous framework for their analysis has been relatively slow to evolve. I believe that a comparative examination of the dynamics of cultural commerce between the Galician and Catalan intellectual communities in Cuba, and their nationalist or protonationalist brethren on the peninsula in the first part of this century, may prove helpful in furthering the search for a suitable theoretical model of analysis. In both cases, the community of nationalistoriented intellectuals on the island, centered in the Galician case around the figure of Manuel Curros Enriquez an in the Catalan case around that of Josep Conangla, appears to have served as a sort of intellectual and cultural vanguard for the burgeoning movements of national identity on the peninsula. By imagining strategies that could not have been easily conceived of or implemented on the Peninsula, they effectively pushed the home movements toward postures of

3 That the imprint of the emigrant experience in Galicia should manifest in this more "physical" fashion makes a good deal of sense when we consider both the historically low level of literary and cinematic production in the autochthonous language of the nation and the fact that, for many there, the emigrant experience is still fairly recent and thus not yet casily amenable to the process of mythogenesis implicit in most literary and cinematic treatments of the phenomenon. In terms of the "problem" of relatively low levels of autochthonous literary production, a similar process can be observed in the Basque Country. There, it seems, the managers of the discourse of national identity have sought to ameliorate the issue by "filling out" their core repertoire of signs and symbols with elements drawn from other realms of creative human activity: "traditional" sports, painting, sculpture, architecture, and more recently, film. For more on the role of the plastic arts in the construction of Basque identity see Martinez Gorriarán. 
greater self-reliance vis à vis the Castilian center. The parallel, but not necessarily congruent, experience of the two diasporic communities in this regard suggests a need to perhaps begin exploring more fully the role of such "cultural intersystems" and their relation to the construction and maintenance of national identities in other places.

Since the publication of Anderson's Imagined Communities (1983), the belief that national identities are culturally constructed entities has gained widespread acceptance. Even-Zohar's inquiries into the question of national identity also start with this fundamental supposition. But unlike Anderson, whose defense of the idea beginsand largely ends-with this fecund intuition, the Israeli scholar ambitiously seeks to hypothesize the rules of systemicity governing the creation and maintenance of such "national" cultural entities. Expanding upon the notion of "symbolic goods" or "symbolic capital" developed by Bourdieu (29-14I; quotation 74-75), he suggests that the success of national culture-planning efforts is highly dependent on the richness ${ }^{4}$ of the socio-semiotic repertoire fashioned and presented by the movement's sign-making elite ("Role" 27). The personal inventiveness, of these "pedagogues of nationhood" (Harrington, The Pedagogy 1-37; quotation 12,17 ) is obviously a factor in the creation of the necessary cultural "stocks" and by extension, the sense of loyalty necessary for creating and maintaining a successful national entity.

However, the success of such nation-building efforis is also heavily mediated by the particular system's pre-existing volume of appropriate cultural tools and models as well as the institutional and marketplace realities of the society within which it operates. For example, those cultural entrepreneurs initiating a repertoire designed to challenge the established set of options concerning the conceptualization of national identity, as was in fact the case in both Galicia and Catalonia in the first third of this century, will frequently find that its access to institutional resources, and thus potential cultural consurners, is effectively blocked. And if, as was certainly the case in Galicia, the system from which the insurgent set of options is derived also suffers form an relatively low rate of cultural production, nationalist activists will often recur to the tactic of importing cultural models, and even fully constituted cultural artifacts, from an outside system. As I have argued elsewhere, ${ }^{5}$ such cultural transfers were numerous and of considerable strategic importance on the intra-peninsular level in the first great

4 By "richness" he means the ability to present a wide variety of potential options for resolving the social challenges with which the nationalist insurgency or establishment is inevitably faced.

5See "Invenciones de Españas" and The Pedagogy 188-262. 
flowering of the so-called "peripheral" nationalist ideologies in Spain in the period from 1906-1923. There is also a small body of literature that touches on the importance of extra-peninsular cultural commerce during the same era. ${ }^{6}$

However, cultural transfer between the Catalanist and Galicianist activists on the peninsula and their co-religionists in Cuba would not appear to fit neatly into either of the these two functional schemas. Insofar as they viewed themselves as contributing to, and being in dialogue with, the particular set of cultural options aligned with the various national projects on the Peninsula, it could be said that they were, in fact, agents of these cultural systems. ${ }^{7}$ At the same time however, their "performance" in this role could not help but be inflected by the very different set of institutional realities informing their daily life in the Caribbean. One such factor was the artificially inflated economic power granted to Europeans under Cuba's slavebased and, after 1886, apartheid-like economic systems. This meant that even very poor and culturally disadvantaged Catalans and Galicians could reasonably expect to "achieve" a solid, middle class existence within a short time of their arrival on the island, and with it, access to means of cultural production that would have been well beyond their grasp in the Peninsula. Another was exposure to (and for some, a parallel participation in) a Cuban nation-building project that, owing to its anti-imperialist foundations, generally had a much more socially and politically progressive cast than the more important discourses of national identity then being articulated in either Galicia or Catalonia. ${ }^{8}$ In short, the interystemic position of the Galicians and

6 Balcells $42-43$ and Payne 94-95 briefly mention the influence of other European discourses of identity development of Catalan and Basque nationalist movements during the first part of twentieth century. Cacho Viu 46-148 underscores the important, if stifl often overlooked, importance of French thought in shaping the nationalist outlook of Eugeni d'Ors in his phase as the prime pedagogue of nationhood in Catalonia (1906-20). Núnez Seixas, "El mito" and Mảiz, "Raza y mito" have analyzed Galicia's tendency to view Ireland as a prime source of cultural tropes and ideas during the first part of the twentieth century.

7 I mention the multiplicity of nationalist projects on the Peninsula because it is important to bear in mind that many (perhaps even a majority) of the Catalan and Galician immigrants living in early twentieth-century Cuba, identified quite strongly with the long-standing "Spanish" vision of national identity with its clear emphasis on the primacy of the Castilian language and cultural system.

8 The position of a late-nineteenth or early twentieth century nationalist activist from Catalonia or Galicia living in Cuba was rife with contradictions and conflicts. Perhaps the most evident of these is the fact that their ability to articulate schemes of identity that were markedly more progressive and socially inclusive than those garnering the greatest amount of political capital in their respective homelands (e.g. the Catalan Lliga) was largely a result of their racially determined position of authority within Cuban sociery. Put another way, those Catalans and Galicians that saw their native 
Catalans in Cuba, that is, their ability to participate in a cultural system without being limited by many of its standard set of strictures, allowed them to exercise an unusual amount of influence on the peripheral movements of identity then gaining strength on the Peninsula.

There are two major ways in which emigrant communities can affect home-borne movements of national identity. The first and most evident is by providing economic support that makes possible the growth of the creation of the type of cultural goods (such as national histories, dictionaries and the like) necessary to for the creation of allegiance or proneness (Even-Zohar, "Culture Repertoire" 396) among the population of the would-be polity. The second, which sometimes overlaps with the first, is in the more specific realm of providing new cultural and political options that could not be easily conceived of in the home system.

The experience of the cultural commerce between the Galician emigrant community in Cuba and the Regionalist/Nationalist movement on the peninsula is largely subsumed under the first model. Galician emigration to Cuba was heavier in volume than that of the Catalans. It began in earnest during the 1880 s and appears to have reached first its numerical peak in the first two decades of the twentieth century (Vázquez González; Iglesias Garcia), Owing to their heavily rural provenance (Naranjo Orovio), the level of political consciousness among the great majority of the Galician immigrants to the island was, at least through the mid-I870s, relatively low, especially in terms of their adherence to what would later come to be termed galeguismo. However, as the island began to provide small but significant numbers of them with a certain degree of economic security, things began to change. These economic transformations within the Cuban-based Galician community on the island coincided with important cultural transformations back on the peninsula. There, the Rexurdimento, the vaguely revanchist movement which had been formed around the poeric triad of Rosalía de Castro,

lands as being unjustly subjugated by "Spanish Imperialism," had to comprehend on one level or another that it was the social stratifications forged during the the previous four centuries of imperial rule that afforded them an enlarged radius of political and social action on the island. Another problem concerned the issue of the immigrant's "moral responsibility" to participate in the nation-building process of his adopted homeland. In the period previous to 1898 , this involved a fairly stark choice: to participate (or not) in the long-running war of national liberation. Thereafter, the issue revolved around the question of whether participation in the Cuban drive to build and maintain national institurions should be considered a pre-condition to "using" the island as a platform for nationalist movements on the Peninsula. Josep Conangla spoke quite eloquently to this thorny issue in a series of articles published in 1916. See "Catalanistes-cubans," "Catalunya enfront," "Per la causa catalana" and above all, "La ciutadania adoptiva." 
Eduardo Pondal, and Manuel Curros Enríquez in the I860s and 705 had begun to give way to the more politically explicit Regionalism of Manuel Murguia's and Alfredo Brañas, whose well-known El regionalismo was published in $1889 .{ }^{10}$

Though this Galician Regionalism has often been compared to the Catalan regionalism of the same era, there were, ${ }^{\mathrm{I}}$ in fact, important differences between the two movements. It is no coincidence, in my view, that Brañas's prime doctrinal text should bear the same title as the book produced by Mañé y Flaquer in Catalonia some two years earlier. Indeed, a side by side reading of the two texts reveals the Galician thinker's considerable debt to the conservative variety of Catalan regionalism espoused by the director of El Brusi. But there was nothing like Almirall's Catalan particularisme to confront Brañas's highly traditional view of the Galician reality. Nor was there anything remotely comparable in these years to his Lo catalanisme $(1886)^{12}$ or Prat and Muntanyola's Compendi de la doctrina catalanista (1894) when it came to the strategic use of the autochthonous language. Both Brañas and the marginally more progressive Murguía wrote almost exclusively in Castilian.

Perhaps the most striking proof of the fundamentally conservative cast of the movement was the treatment it accorded Manuel Curros Enríquez in the years following the appearance of his much-lauded Aires da miña terra (1880). Owing to his fervent anti-clericalism and embrace of Pi i Margall's Republicanism, the poet and journalist was roundly ostracized by the Galician ecclesiastical and governmental establishments. He was eventually tried and condemned for the allegedly blasphemous content of Aires in the months just after its publication. Though the sentence was revoked the next year, it made

9 For a useful summary of Murguía's importance to the development of Galician nationalism see Beramendi, Introducción.

to For an excellent overview of Brañas's work see Măiz.

In In Galicia there are even some that sustain that Brañas was a prime influence on the development of Catalan regionalist and nationalist thought. This oft-repeated cliché would seem to have its origins in a statement Cambó made at a meeting with members of Solidaridad Gallega in Madrid in 19ro. "Yo acompañé a vuestro malogrado Alfredo Brañas en su excursión por Catalonia, $y$ os he de decir que nos enseñó tambièn un gallego a conocer el regionalismo real y del porvenir, porque los catalanes cultivaban esto: el regionalismo del pasado" (Durán 364 ). To conclude from this that Brañas was an important influence in Catalonia seems, more than anything else, a case of wishful thinking. Brañas is not a key referent in any of the Catalanist literature of the time. Moreover, it must be remembered that Cambó was a gifted politician who was, in his meeting twith the Galician solidarios, basically looking to gain their support for his own upcoming electoral battles. Therefore, I tend to agree with Durán's assessment of the much repeated statement when he siys: "me suena a cuca galantería de Cambó" (364).

12 For a strong critical anthology of many of the important philosophical arguments contained in Almirall's long and, at times, repetitive text, see Solé-Tura, Ideart. 
Curros deeply aware of his vulnerability within Galician society. Xesús Alonso Montero has said referring to these events, "cuando Curros fue excomulgado y procesado, la actitud pública de la mayoría de los escritores, de los intelectuales y universitarios gallegos fue de silencio y cautela" (quoted in Carré I4). Aware that he could not express his himself freely in his homeland, Curros fled to Madrid in the early 1880 . There, while earning a living as a journalist at El Porvenir, and later El Pais, he displayed an uncommon interest in effecting a cultural commerce with Portugal, ${ }^{13}$ a country with evident cultural and linguistic similarities to his homcland and also a place where Republicanism was much more widely extended among the intellectual class than in Spain. During this time, he also demonstrated an early understanding of how the Galician communities overseas could be used to leverage one's bargaining position on the Peninsula. ${ }^{14}$

In 1894, he boarded a transatlantic ship with the idea of emigrating to Mexico. En route, he disembarked in Havana and decided to stay, founding his own newspaper, La tierra gallega shortly thereafter. He soon discovered, however, that the political attitudes of many in the Galician community on the island were not all that different from those that had confronted him at home. The publication failed after two short years of operation due primarily to the diasporic community's general distaste for his sharp-edged style of political and social commentary. Faced with the reality of the Galician cultural system's inability to create and/or sustain truly progressive political options either at home or abroad, a somewhat chastened Curros began, in the latter part of the 18 gos to work on projects aimed at widening the set of cultural options available to his home-based countrymen.

Since founding the weekly newspaper El Eco Gallego in 1878 and the famous Centro Gallego of Havana one year later, Waldo Álvarez Insúa had been the community's point man on such cultural pursuits. From the moment of his arrival on the island, Curros clashed with Álvarez Insúa on issues relating to style, politics, and the business. Despite their personal differences, however, the two coincided in a desire to have the Centro Gallego unde:write the publication of Murguia's Historia de Galicia, an initiative that came to fruition a

${ }_{13}$ For more on Curros's lusophilism sec "Curros" and "Sobre la lira lusitana" by Vázquez Cuesta.

14 In 1887 , Curros became involved in difficult negotiations concerning the publication of his second book, $\mathrm{O}$ divino sainete. When his publisher offered him a contract based on an estimated run of 700 copies in the Spanish market, Curros angrily rejected the offer claiming that he would be able to sell a thousand copies in both Buenos Aires and Havana. A short time later, he received a contract based on his "transatlantic" estimate of total sales. See Casares 46. 
short time later. When Álvarez Insúa returned to the Peninsula after el Desastre, Curros assumed the mantle of cultural leadership within the Galician community of Havana.

In 1905 , the poet from Celanova and another long-time member of the Centro Gallego, Xosé Fontenla Leal, founded the Asociación Iniciadora y Protectora de la Academia Gallega (AIP), an organization dedicated to founding and maintaining an Academia Galega that would "preservar e cultivar o idioma galego" (Núñez Seixas, "Inmigración" 364). Thanks to the support of the Cuban organization, the Real Academia Gallega was chartered later in that same year in La Coruña under the active tutelage of Manuel Murguia. Throughout the first decade of the Royal Academy's operation the Cuban association was virtually its only source of financial support. Thus it is no exaggeration to say that the important national cultural goods produced by the Academy, such as the Castilian-Galician dictionary it began publishing in 1913, might not have been created, (or would have been created much later) were it not for the initiatives taken by the Galician community in Cuba. The importance of this fraternal assistance in the realm of language policy becomes even more apparent when we take into account the difficulty that many Galicians, even among those of marked Regionalist and Nationalist sympathies, still had in conceiving of Galician as a tool for written discourse. ${ }^{15}$

No doubt aware of the important galvanizing effect that popular choirs had performed in the consolidation of group identity in Catalonia at the turn of the century, Curros encouraged the formation of such groups among the Galician community in Cuba. An important outgrowth of these activities was the commissioning of the Hino Galego by the aforementioned Fontenla Leal. With Curros's moral support (as well as the financial largesse of the Centro Gallego), Fontenla commissioned the Cuban-based Pascual Veiga to ser the famous poem Os pinos, of Eduardo Pondal, to music. The premiere performance of this fundamental symbol and tool of national pedagogy took place not in Galicia, but in Havana in December of 1907. Curros was also instrumental in assuring that two of galeguismo's more important human "monuments", the husband and

${ }_{15}$ As late as the fall of 1917 , Vicente Risco, who would eventually become one of the great pioneers in the promotion and use of $\mathrm{Galician}$ prose in both public and literary life, viewed his native tongue in decidedly inferior terms. Francisco Bobillo attributes to Risco the following words which appeared in an unsigned book review in the October issue of La Centuria, which was completely under the future galeguista's editorial control: "Hoy se hace literatura gallega, acaso más gallega que nunca; pero la mejor se hace en castellano. En castellano porque el gallego ya no es lengua literaria; sirve sólo para la sátira y para el regocijo rabelaisianu" (Bobillo 94). 
wife team of Manuel Murguía and Rosalía de Castro, would not fall into poverty in the latter part of their lives; in 1905 he persuaded the Centro Gallego to furnish the retired librarian and his wife with a stipend of so pesos per month.

Curros died in 1908. However, Cuba's role as an incubator for the production of essential national cultural goods for Galicia, lived on after his departure. From 1908 to 1910, Antón Villar Ponte lived in Havana and frequented the tertulia at the Puerta del Sol café along with another important figure of Galician culture, Ramon Cabanillas. The atmosphere of cultural entrepreneurship in Cuba (he was a member of the AIP during his stay on the island) seems to have rubbed off on Villar Ponte, for when he returned to Galicia he wrote his paradigm-changing Nacionalismo Gallego ( 1916$)^{16}$ and, perhaps more importantly, founded the first Irmandades de Fala in conjunction with his brother Ramón. The Irmandades and their official publication, $A$ Nosa Terra proved to be the institutional base from which the Nationalist movement, under the leadership of the Xeneración Nós, would emerge a short time later. The subtitle of this foundational journal -Idearium das Irmandades da Fala en Galicia $e$ a nas colonias galegas d'America e Portugal makes quite clear that the brothers Villar Ponte considered the overseas communities to be fundamental elements in the struggle for a greater recognition of Galician cultural singularity,

During the rg2os the galeguista community in Cuba, like the one at home, became wracked by internal divisions and growing economic difficulties. For a brief time in the early I920s the Xuntanza Nacionalista Galega d'Habana, influenced by the example of the early nationalist movement at home and the Centre Català of the same city, pushed for the establishment of a semi-independent Galicia within an Iberian federation of nations. Soon however, it was coopted by the representatives on the island of the Irmandade Nazonalista Galega (ING) of Risco, who was already moving toward a less stridently political vision of Galician nationalism. As the power of the Xuntanza waned, the cause of radical galeguismo was taken up by the Cuba-based Fuco Gómez and his Comité Revoluzonario Arredista Galego (CRAG), closcly modeled after the Clubs Separatistes Catalans founded on the island a few years before. The CRAG, though quite small, was more strident than any organization

16 Villar Ponte's doctrinal text is believed to be the first of its type in Galicia to make explicit use of the term "nacionalismo" on its cover. It should be pointed out, however, that this apparent lurch toward a more free-standing concept of Galician identity is largely mitigated by a contradictory message contained in the text's sub-title: "nuestra atirmación regional" as well as the fact that it is written in Castilian. 
operating on the Peninsula during the Primo de Rvera dictatorship, and in this sense, can be considered an important bridge to the more new, more left-leaning galeguismo that would emerge after the declaration of the Republic in 1931.

In November of 1938 , Castelao made his famous visit to Cuba. ${ }^{17}$ Though it has been widely celebrated in the years since it took place, it was arguably of much less operative significance than the galeguista activities that took place on the island in the first decade of the century. One reason was, of course, the nearly moribund state of the Republican cause at the time. A second was that the center of gravity of the Galician diaspora in America had, for reasons having to do with the relative health of the Argentine and Uruguayan economies and the consequent demographic decline of Galician emigration to the island, shifted to the Southern Cone. Thus, the event should probably be viewed as much as an homage to a storied past than an attempt to chart aggressive new plans for the Galician future.

As the studies of Yáñez Gallardo and Maluquer de Motes make clear, the greatest influx of Catalans to Cuba took place in the middle decades of the nineteenth century. Though their numbers were never as great as those of the Canary Islanders that preceded them, nor those of the great waves of Galicians and Asturians that were to follow, their heavy presence in the commercial sectors of the economy there appears to have afforded them the means with which to establish the earliest and more financially significant "mutual aid" societies within the Spanish colony on the island. From these associations, such as the famous Sociedad de Beneficencia de Naturales de Cataluña, whose initial concern was the protection, care and feeding of the members of the emigrant community, there emerged, at the turn of the century a number of institutions, such as the Centre Catalì of Havana (1905) and the Grop Nacionalista Radical of Santiago (1905), that became intensely concerned with the promotion of Catalan culture in Catalan, often times in the face of strong objections from both Cubans of non-hyphenated identities and numerous members of the Catalan colony itself.

It is in many ways surprising that institutions with programs of this nature should emerge at a time when the economic position of the Catalan colony in Cuba was one of relative privilege and when the rate of emigration between the northeast corner of the Peninsula and the island had sunk to fairly insignificant numerical levels. However, if we bear in mind the extremely spirited, almost revolutionary-style fervor unleashed by Catalanism on the Peninsula during the first

${ }_{77}$ For more on this, see Neira Vilas. 
decades of the twentieth century, then the intense support for the movement among certain Catalan residents of the island becomes more understandable. ${ }^{18}$

In a recent, and much debated, museum exhibition, these first years of the century were described as a time in which there took place "L'eclosió d'una societat nacional" in Catalonia. ${ }^{19}$ It would perhaps be more accurate to say that these years witnessed the consolidation of one particular model for the reconstruction of a national identity; the highly effective program of culture planning put into effect by Prat de la Riba and his talented band of collaborators in the years immediately following the Desastre of '98. While SoléTura's influential study of the man from Castellterçol has arguably led many to seriously underestimate the degree of "intellectual catiolicity" within the Pratian enterprise, it cannot be denied that his nation-building project still left many of the more progressive and stridently idependentist members of the Catalan intelligentsia feeling somewhat out of the fold.

Josep Conangla i Fontanilles, whose yoluminous and important body of writing has been brought to light in recent years by Joaquín Roy, was just such a person. Conangla first went to Cuba as a military conscript in 1895 at the age 20 . At the conclusion of the war in 1898 , he returned to Catalonia. After publishing a well-received collection of poems about his bitter wartime experiences, ${ }^{20}$ he emigrated to Cuba

18 This intensity of feeling can be glimpsed in a letter that the usually moderate and measured Joan Maragall sent to Joaquim Ruyra just betore Solidaritat Catalana gained an almost total control of the Catalan seats in the Spanish Congress of Deputies in April 1907: "jo crec que tots els catalans que vivim tenint el cor en son lloc hem de donar gràcies a Dẻu d'haver nascut en un temps tan ple d'acció esperançada" (Maragall I, rił G). He expands upon these feelings of enthusiasm in "L'alçament," an article published in La Veu de Catalunya five days later: "Solidaritat és la terra, no ho sents? És la terra que s'alça en els seus homes, No has sentit mai dir alló de: 'Si tal cosa succeís fins les pedres s'alçarien'? Doncs ara som en això: que les pedres s'alcen; que cada home és un tros de la terra nadiua amb cara i ulls i esperit i braç; i la terra no es carlina, ni republicana, ni monàrquica, sinó que és ella mateixa, que crida, que vol son espirit propi per a regir-se; $i$ ho crida en tots els seus fills, republicans, monàrquics, revolucionaris, conservadors, pagesos, ciutadans, blanes i negres, rics i pobres. I mentre duri el crit de la terra no hi ha pobres, ni rics, ni ciutats, ni pagesies, ni partits ni res més sobre d'ella que un gran afany d'acallar-la, i satisfer-la, perquê sols quan ella sia en pau podrá cadascú ser republicà o carlí, pagès, blanc o negre, pobre o ric, d'una millor manera que abans; de la única manera en que pot ésser ben bé lo que sia: això és, en conformitat a la naturalesa que la terra mateixa li donava" (I, 765$)$.

19 The phrase cited above is the heading given to the third part of an exhibition on Catalonia and the Disaster of 1898 that appeared at the Museu d'Historia de Catalunya in the spring and summer of 1998 . The event's depiction of the trajectory of Catalanism as well as the Catalan role in Spanish imperialism generated a great deal of controversy. For fuller sense of the exhibition's contents see Escolta Espanya.

20 See Elegia de la guerra. In the introduction to his edition of Memorias de mi juventud, Roy provides an excellent summary of the critical reaction to the poetic 
in 1905 . Save for two visits to his homeland (in 1920 and 1955 ), he would spend the rest of his life in the Caribbean.

As a youth in Catalonia, Conangla had, like so many in his generation, been deeply affected by the poetic example of Joan Maragall.21 But unlike his literary hero who, despite his many natural points of ideological convergence with the Lliga, strove to remain largely above party politics, the young Conangla became intensely involved in the ranks of the Federal Republicans. From the time he graduated from, as he put it years later, "las abstracciones nebulosas de la segunda enseñanza" (Conangla, "El profundo" 60), he was a committed follower of the party's unquestioned patriarch, Pi i Margall. ${ }^{22}$ In fact, the ideological odd couple of Francisco Pi and Joan Maragall would serve as Conangla's principal guides throughout his long and distinguished intellectual career. ${ }^{23}$ This bent toward heterodoxy is, I believe, a key to understanding Conangla's activities in Cuba.

If there one were to try and pinpoint a single reason for the Pi's overall ineffectiveness as a political leader, it would probably be his failure to take into account the human predilection for engaging in non-rational or "supra-rational" activities. Conversely, it would appear that one of the key reasons for the political successes of the Lliga in the first decades of the century was its very ability to channel the desire for group allegiance-a sentiment that generally transcends rational analysis - into a coherent program of social action. Though Conangla was, by conviction, a man of the rationally constituted left, he clearly recognized the efficacy of the more "religion-based"

collection. One of the book's many positive reviews was written in the Diario de la Marina of Havana by none other than Manuel Curros Enríquez.

21 As he did for so many young Caralan poets of the age, Maragall responded warmly to Conangla's request to write a preface to Elegia de la guerra. In it, Maragall praises the intensity with which Conangla expresses the horror of war and his devotion to Caralonia but questions whether such strong feelings are compatible with the "santa serenitat" $^{\prime \prime}$ ) which the bard of Sant Gervasi viewed as a necessary pre-condition for first class poetry. This commentary reveals much about the essential differences between Conangla and his beloved mentor. The younger man would never shy away from participating in the messy commotion of the public space throughout his long and eventful life. Maragall always sought to maintain the posture of an observer as opposed to an activist when it came to the key social and political conflicts of his time.

22 Conangla's connection to $\mathrm{Pi}$ was more than just ideological. He served as the secretary to Pi's son Francisco Pi y Arsuaga in the years between his first and second residencies in Cuba. He thus had the opportunity (during a visit Francisco Pi "father" made to Barcelona in 1901) to "tratar en la intimidad más sencilla a quien habia yo erigido en mentor político y en gran parte intelectual" ("El Profundo" 60).

${ }_{23}$ Proof can be found in the way he continued to study and publicize the writings of his two heroes well into the final years of his life. See his Cuba y Pi y Margall, L'Apostolat patriòtic de Maragall, and Els altres sentits, in which he analyzes Maragall's Cant Espiritual. 
national culture planning efforts being carried out by the rightleaning followers of Prat on the peninsula.24 This mental agility permitted him to, in effect, co-opt right's potential appeal among the Catalan community of the island, and in this way, free his hands to turn the Centre Catala of Havana into an important laboratory for the creation of an alternative repertoire of options within the Catalan cultural system.

Conangla's clear understanding of culture's potential as a tool for national mobilization is perhaps most clearly evidenced in his Missió social de l'art, an essay read in roio in the section on "Expansió catalana" of the Centre Català of Havana. The vision of the artist outlined by Conangla in the first section of the work is nothing less than that of a high priest who mediates between the material and spiritual realms, a "divinizing" force without equal in the world. His special talents are not to be expended on other individuals but rather in the service of the collective: "Pero l'artista sigan quinas sigan las sevas especials aptituts, será més digne de l'art y de la gloria si se esmersa son talent en profit directe de son poble,... en las lluitas vitalisimas per la llivertat y la felicitat de sa terra" (Missió 18). In many ways, it is a concept of the artist's role in society that is very much in keeping with the one then being articulated in Catalonia by the Lliga-aligned Eugeni d'Ors. What was his Glossari, and the drive he inspired to compile the Almanach dels noucentistes (I911), if not a means to highlight and catalog the existence of such people in Catalan society? However, when it comes time to put forth an example of this type of nationalist pedagogue, Conangla recurs not to d'Ors's wellpublicized pantheon of exemplary Catalan intellectuals, but rather to the figure of José Marti, the socially progressive martyr of his adopted country. ${ }^{25}$ In short, he seemed to be suggesting that the highly selfconscious culture-planning methods of the right could, indeed, should be applied to, and utilized by, the political left.

24 When I speak of the "religious" basis of the the Lliga's program of national mobilization, I use the term not in the narrow sense (e.g. of its relations with the Church which were quite strong in the sector vigata of the party led by Torras i Bages), but rather its tendency to conceptualize the national ontology in ways that challenged rational modernity's linear conceptions of space and time. For more on this important aspect of turn-of-the-century movements of national identity in Spain and Portugal, see Harrington, "Literatura e nacion". It is interesting to note that, unlike the vast majority of Spanish Republicans of his era, Conangla tvas a "creyente" (Roy, "Esbozo" 30). It seems reasonable to assume that this openness to notions of transcendence in his personal life probably predisposed him to an acceptance of similar mental schemas in the sociopolitical realm.

25 If we were to speak of a third great influence in the life of Conangla, it would no doubt be Marti who, in a sense, combined the prime attributes of his two other heroes. As in the case of $\mathrm{Pi}$ and Maragall, he would return to the study of the great Cuban patriot in the last years of his life. For more on this, see his Marti y Cataliña. 
The acute awareness of the need to create political options within a sturdily constructed cultural matrix is evident in his ongoing dialogue within political realities of his homeland. When the conservative Lliga, under the leadership of Prat, began its intense campaign to create an institutional basis for the perpetuation of Catalan culture, Conangla strongly urged the Catalans of America to support the fledgling institution of autonomy in every way possible, including with financial contributions. "La missió de la Mancomunitat no ha de ser-nos indiferent als catalans d'Amèrica, en el sentit econòmic, com no ens ho és en el sentimental i patriòtic... ens sembla que pertoca als catalans d'Amèrica l'honor i l'obligació de contribuir, voluntariàment, cada u segons les seves possibilitats, a enrobustir els ingressos de la Mancomunitat catalana" ("Els Catalans d'Amèrica" 15). However, he never confused an embrace of the new institution with support for the particular views of its founding fathers For example, shortly after making these patriotic exhortations, he takes Cambó to task for his use of obfuscatory language on the issue of Catalan separatism ("Cambó" 20-23). For the Federal Republican Conangla, who would become the driving force behind the creation in 1922 of the Clubs Separatistes, of the island, an outright divorce from the center was a necessary pre-condition for the creation of a Federation of Iberian nations. From the way he saw it from his perch in Havana, there was no reason to be anything but straightforward about this reality.

In the aforementioned series of articles from 1916 which grew out of a polemic with other Cuban-based Spanish intellectuals over their "right" to comment on, and participate in, peninsular affairs, Conangla spells out and defends a position that demonstrates an acute awareness of the intersystemic positionality of many diasporic intellectuals. ${ }^{26} \mathrm{He}$ argues, in effect, that his decision to adopt Cuban citizenship was a logical response to the Madrid-based government's habit of artificially imposing Spanish citizenship on those born in Catalonia. In other words, given that his membership in the only nation of which he feels a part has never been ratified by law-a fact which demonstrates the essentially capricious relationship between political regimes and national identities - it is perfectly logical that he, and others like him, should pragmatically seek the place of residence that provides them with the greatest possible opportunity to effect change in their homeland. This highly self-conscious posture on the role of the diasporic intellectual would seem to suggest that attacks such as those aimed at Cambó and others were well-calculated for their potential to affect the course of home-borne political debates.

26 See nove 9 above. 
Conangla continued this policy of semi-revolutionary politics undergirded by Jocs Florals throughout the late teens and early twenties. ${ }^{27}$ When Catalanist politics turned sharply leftward owing to the Lliga's failure to extract institutional guarantees of autonomy from Madrid in return for their participation in the central government (and of course, the subsequent repressive policies of Primo's dictatorship) Conangla and the many Catalanist entities with which he was associated on the island suddenly gained greater relevance. Having kept the flame of left-leaning independentism alive during the years of the Lliga's hegemony, the Club Separatista led by Conangla, Josep Pineda, Josep Murillo and Claudi Mimó was now in a position to finally begin having the influence they had longed to attain since their founding of La Nova Catalunya in 1905 . That they were relatively prosperous while Macià was struggling financially in exile only enhanced their leverage within the movement. After the disaster at Prats de Molló in November of 1926, they began to sense that they were in an especially strong position to curry favor with the most charismatic Catalanist leader remaining on the political map.

According to Ramon Fabregat (90), the Centre Català of Havana first asked Macià to come to Cuba in 1922. It did so again in 1924. Finally, in late 1926 , while he was still in a French prison as a result of the fiasco in the Pyrenees, Macià accepted the offer to travel to America ${ }^{28} \mathrm{He}$ finally arrived in Cuba (after visiting the Catalan communities of Uruguay, Argentina and Chile) in late August 1928, accompanied by Ventura Gassol. They were met by the leading members of the Club Separatista and the two-man advance party of Joan Macià (Francesc's son) and Josep Carner-Ribalta. Carner-Ribalta had arrived in Cuba some months earlier and had been working closely with Conangla to coordinate the activities thát would take place during Macià's visit (Carner-Ribalta 130). We can probably assume that he had some input in the composition of the two historic documents written by Conangla and submitted to Macià at the Assamblea Separatista in September: the "Constitució Provisional de la República Catalana" as well as the "Bases del Partit Separatista Revolucionari de Catalunya."

${ }_{27}$ The reference is not metaphorical. In 1923, the various Catalan societies of Cuba joined together to sponsor just such a poetry contest. Conangla served as the president of the Jurat Qualificador of the event. For more on this, see Memorial dels Jocs Florals.

28 Enric Jardí suggests that Cambó might have had something to do with Macià's decision to finally undertake the much-anticipated trip to America ( 58 ). The specific decision to attend the Assamblea Separatista in Havana, appears to have been made in September of 1927 in response to an invitation made by Conangla, writing on behalf of the Club Separatista of Havana (Fabregat, 83; Conangla, "Dictamen" 181 ). 
Though would Macià stray from many of the ideological principles enunciated in Cuba when given his chance to govern in $1931,{ }^{29}$ there can be no denying the symbolic importance of the events that took place in Havana in September and early October 1928. At a time when the Primo de Rivera dictatorship had severely constrained nationalist aspirations within Catalonia, the Cuban group provided not only a space for dialogue but also a new institutional basis for progressive Catalanism. With its bold and unambiguous call for an independent Catalonia, Conangla's group in Havana effected a radical break with the with the dominant accidentalist tradition within the discourse of identity in Catalonia. In so doing, they paved the way for the much more vigorous pursuit of Catalan national prerogatives during both the Republic and the long years of the Franco dictatorship.

At the outset of the twentieth century, the Galician and Catalan movements of national identity, though both clearly rising in strength, found themselves with a need to create more of the type of cultural goods and tools that appear to be necessary for the creation and consolidation of insurgent cultural systems. Owing to their position of cultural intersystemicity, the emigrant communities of both nationalities on the island of Cuba were able to create cultural items that would have been very difficult, if not impossible to generate at home. In the Galician case, these were some of the basic institutions and signs of a national culture. In the case of Catalonia, which was considerably more advanced than Galicia in the realm of generating nationalizing institutions, the emphasis was more on the creation of new political options which had the effect of facilitating the adoption of more markedly more radical postures within the nationalist discourse at home.

THOMAS S. HARRINGTON

TRINITY COLLEGE

29 Macià's failure ta put ultimately the priciples of Conangla's document into practice during the Republic gained him the lasting enmity of many members of the separatist groups on the island. See Roy Introducció xxv-xxvii. 


\section{WORKS CITED}

Almanach dels noucentistes. Barcelona: Horta, I9II.

Almirall, Valentí. Lo Catalanisme. Barcelona: Edicions 62, 1979.

ANDERSON, Benedict. Imagined Communities: Reflections on the Origin and Spread of Nationalism. London: Verso New Left Books, 1983.

BalCells, Albert. Catalan Nationalism: Past and Present. Trans. Geoffrey Walker. New York: St. Martin's, I996.

BerAmendi. Xusto G. Introducción. Galicia, by Manuel Murguía. Vigo: Edicións Xerais, 1982.

- Nacionalismo gallego. La ideología de Vicente Risco. Madrid: Akal Editores, $198 \mathrm{I}$.

BOURDIEU, Pierre. The Field of Cultural Production: Essays on Art and Criticism. Ed, Randal Johnson. New York: Columbia UP, 1994.

BRANAS, Alfredo. El regionalismo. Barcelona, 1889 . Facscimile version. La Coruña: La Voz de Galicia, 1982.

CACHO Viu, Vicente. Revisión de Eugenio d'Ors. Barcelona: Quaderns Crema y la Residencia de Estudiantes, 1997.

CARNER-RIBALTA, Josep. De Balaguer a Nova York passant per Moscou i Prats de Molló. Paris: Edicions Catalanes de Paris, 1972.

Carré Alvarellos, Lois. Manuel Curros Entíquez, sua vida e sua obra: (ensaio bio-bibliografico). Buenos Aires: Ediciones Galicia del Centro Gallego de Buenos Aires, 1953.

CASARES, Carlos. Curros Enriquez. Vigo: Galaxia, 1980.

Conangl.a I Fontanilles, Josep. "Bases del Partit Separatista Revolucionari de Catalunya." La Constitució de l'Havana $i$ altres escrits. 254-55.

-. "Cambó i el catalanisme." La Constitució de l'Havana $i$ altres escrits. 20-23.

- "Catalanistes-cubans i catalan-espanyolistes." La Constitució de l'Havana $i$ altres escrits. 24-28.

- "Catalunya enfront d'Espanya." La Constitució de l'Havana $i$ altres escrits, 28-32.

- "Constitució provisional de República Catalana." La Constitució de l'Havana $i$ altres escrits. 218-53.

- Cuba y Pi y Margall: estudio preliminar seguido de un anexo con todos los articulos y discursos de Pi y Margall en pro de la autonomia y luego de la independencia de Cuba. La Habana: Editorial Lex, 1947.

-. "Dictamen acompanyatori de la ponència de la constitució provisional de la República Catalana." La Constitució de l'Havana $i$ altres escrits, $18 \mathrm{I}-2 \mathrm{1} 8$. 
-. "El profundo humanitarismo de Pi y Margall." Revista Bimestre Cubana 33 (1933): 59-87.

- Elegia de la guerra. Barcelona: Tipografia Catalana rgo4.

- Els altres sentits. Mèxic: Editorial Xaloc, 1957.

-. "Els catalans d'Amèrica i la Mancomunitat: contribució voluntària per Catalunya." La Constitució de l'Havana i altres escrits. I4-I6.

- "La ciutadania adoptiva (limit prudencial i legal dels seus drets i deures)." La Constitució de l'Havana i altres escrits. 37-60.

- La Constitució de l'Havana i altres escrits. Ed. Joaquín Roy. Barcelona: Edicions de la Magrana, 1986.

-. L'Apostolat patriòtic de Maragall. Habana: Burgay y Cía. 1953.

- Martí y Cataluña: examen retrospectivo de unos conceptos inverosimiles, atribuidos al gran apóstol cubano. La Habana: Comisión Nacional Organizadora de los Actos y Ediciones del Centenario y del Monumento a Martí, 1954.

- Memorias de mi juventud, en Cuba: un soldado del ejército español en la guerra separatista, $1895-1898$. Ed. Joaquim Roy Barcelona : Ediciones Península, 1998.

- Missió social de l'art-Misión social del arte. Habana: Imprenta Comas y López, rgio.

- "Per la causa catalana." La Constitució de l'Havana i altres escrits. 33-36.

Curros Enriquez, Manuel, Aires da miña terra e outros poemas. Vigo: Galaxia,1985.

DuplÁA, Cristina. "La ben plantada o el ideal feminino del 'Noucentisme'." Revista de Occidente 97 (1989): 79-92.

DURÁN, J.A. Agrarismo y movilización campesina en el pais gallego (1875-1912). Madrid: Siglo XXI, 1977.

Escolta Espanya: Catalunya i la crisi del 98: Musen d'Història de Catalunya, ig de març-l3 de setembre de 19g8, Barcelona: Proa/Generalitat de Catalunya, 1998.

EVEN-ZOHAR, Itamar. "Culture Repertoire and the Wealth of Collective Entities." Under Construction: Links for the Site of Literary Theory. Essays in Honour of Hendrik Van Gorp. Ed. Dirk de Qeest. Leuven: LUP, 389-403.

-. "Laws of Literary Interference." Poetics Today 2.I (Spring 1990): 53-72.

-. "The Role of Literature in the Making of the Nations of Europe: A Socio-Semiotic Examination." Applied Semiotics / Sémiotique appliquée. I (March 1996): 20-30.

FABREGAT, Ramon, ed. Macià, la seva actuació a l'estranger. Mèxic: Edicions Catalanes de Mèxic, 1952.

Harrington, Thomas. "Invenciones de Españas." Claves de Razón Práctica 82 (mayo de 1998): 50-51. 
-. "Literatura e nación." Grial 134 (1997): 379-92.

-. "The In-House Nationalist Pedagogy of Antoni Ribas's La ciutat cremada." West Virginia Philological Papers Papers 43 (1998): $122-$ 30.

-. "The Pedagogy of Nationhood: Concepts of National Identity in the Iberian Peninsula 1874-1925." Diss. Brown U, 1994.

Iglesias GARCiA, Fe. "Caracteristicas de la inmigración española en Cuba 1904-1930." Españoles hacia América: la emigración en masa, 1880-1930. Ed. Nicolás Sánchez-Albornoz. Madrid: Alianza Editorial, I988. 270-95.

JARDi, Enric, Francesc Macià. Barcelona: Edicions 62, 1991.

MAIz, Ramon. Alfredo Brañas: $O$ ideario de rexionalismo católico tradicionalista. Vigo: Galaxia, 1983.

-. "Raza y mito céltico en los orígenes del nacionalismo gallego: Manuel M. Murguia," Revista Española de Investigaciones Sociológicas 25 (1984): 137-80

MALUQUeR DE MOTES BERNET, Jordi. Nación e inmigración: los españoles en Cuba. Oviedo Ediciones Jucar, 1992.

MAÑ̂́ Y FLAQUER. Juan. El Regionalismo. 2nd. ed. Barcelona: Imprenta Barcelonesa, 1887.

Maragall, Joan. Obres Completes. Obra Catalana. Barcelona: Editorial Selecta, I981.

MARTÍNEZ GORRIARAN, Carlos. Estética de la diferencia: el arte vasco y el problema de la identidad, 1882-1966. Donostia: Alberdania, 1995.

Memorial dels Jocs Florals Catalans de Cuba. La Habana: Burgay y Cia, 1923.

Naranjo Orovio, Consuelo. Del campo a la bodega: recuerdos de gallegos en Cuba (siglo XX). Sada, A Coruna: Ediciós do Castro, 1988.

NeIra Vilas, Xosé. Castelao en Cuba. Sada: Ediciós do Castro, 1983. NúÑ̄Z SEIXAS, Xosé M. "El mito del nacionalismo irlandés y su influencia en los nacionalismos gallego, vasco y catalán (1880-1936)." Spagna contemporanea 2 (1992): 25-58.

-. "Inmigración e galeguismo en Cuba (1879-1939)." Grial II5 (I992): 35085.

-. O galeguismo en America, 1879-1936. Sada: Edicios do Castro, 1992.

PAYNE, Stanley. Basque Nationalism. Reno: U of Nevada P, 1975.

PRAT DE la RiBA, Enric, and Pere Muntanyola. Compendi de la doctrina catalanista. Sabadell: Imprenta de lo Catalanista, 1894.

Reguant, Montserrat. Etapas reivindicativas de la teoria nacional catalana: Verdaguer, Oller y Prat de la Riba. New York: P. Lang, 1997.

RoY, Joaquim. Catalunya a Cuba. Barcelona: Barcino, 1988.

-. "Esbozo biográfico." Memorias de mi juventud, en Cuba: un 
soldado del ejército español en la guerra separatista, 1895-1898. Ed. Joaquim Roy Barcelona: Ediciones Península, 1998. 7-36.

- Introducció. La Constitució de l'Havana $i$ altres escrits. By Josep Conangla i Fontanilles. v-xxxii.

- Josep Conangla i Fontanilles (Montblanc 1875-l'Havana I965): patriarca del nacionalisme català a Cuba. Tarragona: El Mèdol, 1999.

SOLE-TuRA, Jordi. Catalanisme i revolució burgesa: La sintesi de Prat de la Riba. Barcelona: Edicions 62, 1967.

- Ideari de Valenti Almirall. Barcelona: Edicions 62, 1974.

VAZQUEZ CUESTA, Pilar. "Curros, os escritores portugueses e o Ultimatum.” Grial 46 (1974): 417-29.

-. "Sobre la lira lusitana de Curros Enríquez." Grial 20 (1968): 149-54.

VAZZUEZ GONZÁleZ, Alejandro. "La emigración gallega. Migrantes, transporte y remesas." Españoles bacia América: la emigración en masa, 1880-1930," Ed. Nicolás Sánchez-Albornoz. Madrid: Alianza Editorial, 1988. 80-104.

VILLAR PONTE, El nacionalismo gallego: nuestra afirmación regional. La Coruña: [n. p.], I9I6.

YÁNEZ GALlARDO, César. "Cataluña: un caso de emigración temprana." Españoles hacia América: la emigración en masa, I880-1930. Ed. Nicolás Sánchez-Albornoz. Madrid: Alianza Editorial, I988. I23-42. 